\title{
The Effects of Preoperative Education, Marking and Adequate Positioning of Stoma on Self-Esteem and The Quality of Life of Patients with Intestinal Ostomy and Their families
}

1 Vesna Konjevoda

2 Snježana Čukljek

2 Sanja Ledinski Fičko

2 Martina Smrekar

1 Clinical hospital Sveti Duh, Zagreb, Croatia

2 University of Applied Health Sciences, Zagreb, Croatia

Article received: 14.05 .2020 .

Article accepted: 15.06 .2020 .

https://doi.org/10.24141/2/4/2/6

Author for correspondence:

Vesna Konjevoda

Clinical hospital Sveti Duh

Sveti Duh 64, Zagreb, Croatia

E-mail: konjevoda.vesna@gmail.com

Keywords: preoperative education, marking and adequate positioning of stoma, quality of life

\section{Abstract}

Aim. The purpose of this systematic review is to examine all available research studies on quality of life of ostomy patients and their families, which is contingent upon the effects of adequate preoperational education, the best and most acceptable ostomy site marking on the patients' abdomen, and subsequently, the effect on the ostomy patients' self-esteem.

Methods. A literature search was carried out using scientific electronic databases - Science Direct, PubMed and Medline. Analysed period was from 2010 to 2016 in order to get insight into the most recent findings. Search terms included preoperative education, stoma marking, quality of life, self-esteem, influence on family life. Overview of articles was made in three stages.

Results. We found 1440 scientific articles. In the first stage, we eliminated 1271 articles because they were unsuitable. In the second stage, we analysed 34 articles and made a conclusion based on 13 full text available articles.

Conclusion. The patient is content while being treated in the hospital; however, only after the patient has been released do the hardships occur, which are often the main cause of discontent, isolation, anxiety, and fear - thus resulting in diminished quality of life. Preoperational education and marking the most acceptable place for ostomy procedure significantly affect the selfesteem and the quality of life of ostomy patients and their families. Ostomy patients need to be followed up, and the home care system, as well as the support systems of public health care for patients with a gastrointestinal ostomy, need to be strengthened. 


\section{Introduction}

Colorectal cancer is prevalent among the malignant tumours of the gastrointestinal tract, and it affects both sexes almost equally. The most common treatment for colorectal cancer is surgery, and the result of $10 \%$ of the cases is a permanent ostomy. There are different types of ostomy, but colostomy, ileostomy, and urostomy are most common (1). Surgical procedure of implementing stoma is a health-saving or lifesaving surgical procedure. The number of people living with a stoma is about 1.5 million all over the world. Unfortunately, despite many prevention measures and national prevention programmes, the number still increases. Ostomy is not a handicapping procedure. Living well with an ostomy can be achieved through proper patient preparation, education, and planning. Provision of individualized comprehensive care facilitates physical and psychological rehabilitation (1). The predictors of adjustment to ostomy include successful ostomy self-care, satisfaction with body image, the amount of social support, and time elapsed since surgery $(2,3)$. Survivor competence related to ostomy care has been described as the most important predictor of positive adjustment to ostomies. Ostomy construction is an important step in the course of a bowel resection or anastomosis and a primary procedure for diverting the faecal stream or alleviating obstruction. Ostomy patients suffer significant physiological challenges that can affect psychological variables and health-related quality of life (HRQOL) (4). The most common underlying conditions resulting in the need for stoma surgery are colorectal cancer (45.8\%), bladder cancer (7\%), diverticulosis (7\%), inflammatory bowel disease $(1.8 \%)$, ileus (7\%), perforations and fistulae (2.6\%), peritonitis, inborn anomalies, gastrointestinal tract injuries (2.9\%), and abnormalities and spine damage resulting in the inability to control the defecation (5). Colitis, ulcerative colitis and Crohn's disease are the most common reasons for performing an ileostomy procedure. Taking into consideration the causes which lead to the need for performing an ostomy procedure, it is clear that ostomy is performed among people of all age groups and of various socio-demographic profiles. The changes resulting from an ostomy procedure are not merely of gastrointestinal and physiological nature, but ostomy also influences self- esteem and positive self-image of the patient, thus prompting changes in the person's family life, as well as the professional, social, and emotional life of an individual, which may result in anxiety and depression $(5,6)$. The postoperative outcome has traditionally been assessed in terms of survival or improvement of disease-related symptoms. These criteria place no emphasis on the patient's overall perception of the impact of the procedure on subjectively experienced distress or wellbeing (7). According to Ross at al. (8), patients with ostomies express aspects of a more negative body image and future prospects, diminished social functioning, and a higher reported level of depression than in patients without a stoma. In addition, according to Gervaz et al. (9), patients with permanent stomas who had undergone abdominoperineal resection had their general QOL improved, but their body image and stoma-related problems were only slightly improved after one year. Alternatively, some studies report that body image or QOL of patients with temporary stomas recover after the repair of the stoma (10). After stoma formation patients should be independent in their own stoma care. According to many research studies that have been conducted so far, stoma nurse specialists have a key role in caring for patients with a stoma, both pre- and postoperatively (11). Salvadena et al. (12), emphasize that marking the spot on the abdomen surface, as well as adequate positioning of the stoma are a priority of preoperational preparations. McKenna at al. (13), compare health-related quality of life in patients receiving preoperative stoma marking by the certified wound, ostomy, and continence nurse (CWOCN) to the health-related quality of life of patients who did not receive preoperative marking. The analysis demonstrated significantly higher HRQOL in the marked group compared to the unmarked group. "Numerous research studies confirm that stoma siting is often regarded as the most important part of preoperative preparation" (13). Marking the abdominal skin at the proposed stoma site takes place after a period of assessment, discussion, observation, consideration, and evaluation that began on the first meeting between the patient and the nurse (14). The sources also highlight that the position of the stoma should allow the patient to manage it independently and to resume their normal activities after recovery. The success of the stoma can depend on its site and the general condition the patient is in. An adequately positioned stoma decreases the chances of ostomyrelated complications, such as peristomal dermati- 
tis resulting from leakage of the pouching system. It may also influence the predictability of a pouch's wear time, the ability of the patient to adapt to the ostomy and become independent and may even help control health care costs (12). Sands at al. (15), highlight the importance surgical techniques, adherence to the basic surgical principles, proper preoperative patient counselling, and pre-operative stoma marking, all of which may prevent many of these complications and enable the surgeon to create the perfect stoma. If any of these should lack, there is a great probability of the occurrence of complications that may result in reoperative surgery to revise the stoma and quality of life. Danielsen et al. (16), compare the costs of treating stoma patients before and after having implemented a preoperational educational programme for them, as well as the programme's impact on the quality of life. The results show that the educational programme for stoma patients improves their quality of life, but a significant difference in the average costs of the overall treatment has not been found. However, a significant difference has been found regarding the reduction of costs related to unplanned readmissions $(p=0.01)$ as well as a reduction in visits to a general practitioner $(p=0.05)$. The life changes that individuals with an ostomy undergo may have psychological and social consequences. For these people, living with a new device in their body may lead to fear, embarrassment, and self-doubt. As Cetolin at al. stress, the family is of fundamental importance, given its role as a form of support to the ostomate. Thus, we cannot neglect the feelings and vulnerability of family members. They need to be provided with support systems - a multi-professional health team could play an important role in informing the family and improving the quality of life of the ostomates, as well as that of the family unit (17).

The purpose of this integrative review of research studies is to explore factors involved in the quality of life of persons with an ostomy, especially regarding education, preoperative stoma marking, and the effect of the new life situation on the ostomate's selfesteem and their family members.

\section{Methods}

\section{The sources of documents}

This methodology updates information related to a specific topic, and it is based on published research studies. The overview of the articles on the topic of quality of life with an intestinal stoma was arranged in PubMed, Sciencedirect and MedLine databases. A literature search was conducted between November 2015 and February 2016. The search terms used were: ostomy education, stoma marking, quality of life, self-esteem and family. In order to acquire more articles related to the topic, a cross-search with the keywords was performed using the Boolean connector AND.

\section{Process of inclusion of documents in the review}

The first stage consisted of ruling out the articles who did not include the topic of quality of life of people with an intestinal ostomy and their family, selfesteem, education, and stoma marking. Because of the immense number of articles found, the time span of the publications was limited to the last five years (2010-2016), in order to get insight into the most recent findings.

The second stage included searching for articles that were available as a free full text. The research studies were then divided into three categories:

1. the influence of education and stoma marking on the quality of life of stoma patients,

2. self-esteem and quality of life of stoma patients,

3. quality of family life of stoma patients.

The third stage encompassed the summarizing of relevant interpretations through meticulous reading, so study design could be analysed.

Figure 1 shows the flow diagram of the study selection process. 


\section{Analysis}

Step 1. The analysis of the appearance of documents was performed.

Step 2. The content analysis was performed.

The influence of preoperative education, stoma marking on the quality of life and self-esteem of a person with an ostomy and their family were the main focus of the review and the results are displayed in the tabular form separately (Table 2-4).
Having gathered all the available research studies in full form, the analysis could commence. They were grouped in three categories, and the focus of analysis included research methods, sample size, and research aims and purposes; we analysed the downsides and searched for guidelines for further scientific research directed towards public health action with the aim to improve the quality of life of intestinal stoma patients and their families.

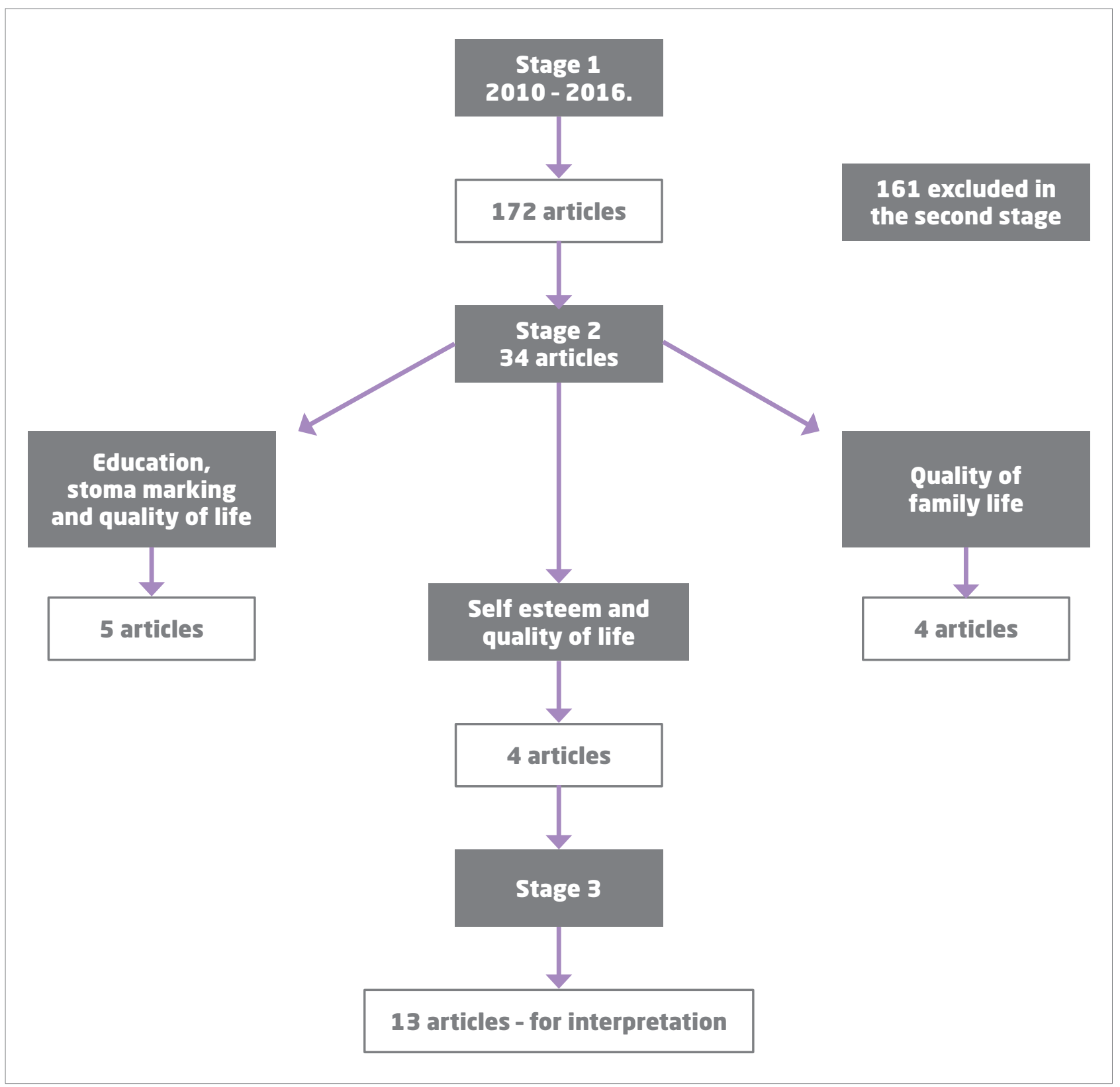

Figure 1 . The flow diagram of the study 


\section{Results}

\section{Table 1. Study design - education and stoma marking=quality of life}

\begin{tabular}{|c|c|c|}
\hline Author & Study type & Methods \\
\hline $\begin{array}{c}\text { Sun V, et al. } \\
(18)\end{array}$ & $\begin{array}{c}\text { Qualitative } \\
\text { analysis } \\
\text { Survey study }\end{array}$ & $\begin{array}{c}8 \text { focus groups } \\
\text { The City of hope QOL Ostomy } \\
\text { specific was used to assess } \\
\text { HRQOL. } \\
33 \text { participants - CRC survivors } \\
\text { with a stoma }\end{array}$ \\
\hline $\begin{array}{c}\text { Danielsen AK, } \\
\text { Rosenberg J. } \\
\text { (16) }\end{array}$ & $\begin{array}{l}\text { Case-control } \\
\text { study } \\
50 \text { patients }\end{array}$ & $\begin{array}{l}\text { HRQOL was measured before } \\
\text { hospital discharge, three and } \\
\text { six months after stoma creation } \\
\text { and educational interventions } \\
\text { involving lay teachers, along with } \\
\text { a health professional teacher. }\end{array}$ \\
\hline $\begin{array}{c}\text { Coca C, } \\
\text { Fernández } \\
\text { de Larrinoa } \\
\text { I, Serrano R, } \\
\text { García-Llana } \\
\text { H. (4) }\end{array}$ & $\begin{array}{l}\text { Multicenter, } \\
\quad \text { quasi- } \\
\text { experimental, } \\
\text { prospective, } \\
\text { longitudinal } \\
\text { study }\end{array}$ & $\begin{array}{l}\text { Two validated scales were } \\
\text { used to determine HRQOL: EQ- } \\
5 \text { D (Spanish version) and the } \\
\text { Montreux questionnaire. } \\
402 \text { patients with intestinal } \\
\text { stoma }\end{array}$ \\
\hline
\end{tabular}

Trninić Z, et al. (7)

\begin{tabular}{|c|c|}
\hline $\begin{array}{c}\text { McKenna LS, } \\
\text { et al. (13) }\end{array}$ & $\begin{array}{c}\text { Quasi- } \\
\text { experimental, } \\
\text { Nonrandomized } \\
\text { cohort } \\
\text { comparison } \\
\text { study }\end{array}$ \\
\hline
\end{tabular}

Quality of life was measured using two instruments:

the European Organization for Research and Treatment

for Cancer (EORTC) QLQ C-30 questionnaire (version

3.0) and the EORTC colorectal module QLQ C-38 questionnaire.

91 patients with colorectal cancer
Study aim

\section{Conclusion}

Pinpointing the biggest challenges that stoma patients suffering from colorectal cancer encounter.

Problems with ostomy location and pouch

To explore a structured patient education programme on health-related quality of life.

To compare HRQOL in a group of patients treated in hospitals that employ nurses specializing in ostomy care and education versus patients who were cared for at hospitals that did not employ nurses specializing in ostomy care and education.

To compare QOL between the stoma and non-stoma CRC patients and compare both groups with a healthy population sample.

Comparison of two groups of patients having had their stoma procedure done in the period from 2008 to 2010 . The experimental group consisted of 35 patients who received preoperative ostomy education and stoma site marking by ostomy and continence nurse. The control group consisted of 24 patients who did not receive preoperative stoma site marking or preoperative education. can be prevented by

Patients enrolled in an health workers show

Their findings strongly suggest that patients

to a nurse specialist in of patients. group when compared
To compare healthrelated quality of life (HRQOL), in patients receiving preoperative stoma marking by a certified wound, ostomy, and continence nurse to patients who did not receive preoperative marking.

Clothing adaptation, problems with equipment, leakage, hernias, activity limitations result from inadequately positioned stoma which preoperational marking. educational programme led by a team of specialised significantly higher HRQOL. undergoing ostomy surgery should be provided access

ostomy care since their results highlight the potential benefit promoting the HRQOL

Significantly better results in physical functioning were observed in the healthy with two other groups of colorectal cancer patients, the group with colostomy and the group without colostomy.

Financial difficulties were significantly more expressed in the group with colostomy than the other two groups.

The patients who underwent stoma site marking reported significantly higher HRQOL than those who did not. 


\begin{tabular}{|c|c|c|c|c|}
\hline Author & Study type & Methods & Study aim & Conclusion \\
\hline $\begin{array}{c}\text { Golicki D, } \\
\text { Styczen P, } \\
\text { Szczepkowski } \\
\text { M. (19) }\end{array}$ & $\begin{array}{c}\text { Multicentre } \\
\text { cross-sectional } \\
\text { study }\end{array}$ & $\begin{array}{l}\text { Stoma patients filled } \\
\text { out (directly or over the } \\
\text { telephone) WHOQOL- } \\
\text { BREF questionnaires } \\
\text { on the day they were } \\
\text { discharged from the } \\
\text { hospital and three } \\
\text { months after discharge. } \\
\text { Control group: patients } \\
\text { of the internal medicine } \\
\text { department }\end{array}$ & $\begin{array}{c}\text { To evaluate the } \\
\text { quality of life using } \\
\text { a validated WHOQOL } \\
\text { - BREF questionnaire } \\
\text { and to identify } \\
\text { limitations to the } \\
\text { quality of life of stoma } \\
\text { patients. }\end{array}$ & $\begin{array}{c}\text { Quality of life at three } \\
\text { months after the surgery } \\
\text { has been assessed as higher. } \\
\text { Limitations regarding patients' } \\
\text { sexual life and working ability } \\
\text { have been identified. }\end{array}$ \\
\hline $\begin{array}{l}\text { Hong KS et al. } \\
\text { (10) }\end{array}$ & $\begin{array}{l}\text { Prospective } \\
\text { observation }\end{array}$ & $\begin{array}{l}\text { Three-part questionnaire } \\
\text { (consisting of body image } \\
\text { scale, self-esteem scale } \\
\text { and depression scale), has } \\
\text { been filled out four weeks } \\
\text { after the operation by } 42 \\
\text { patients with a temporary } \\
\text { stoma (TS) and } 23 \text { with a } \\
\text { permanent stoma (PS). } \\
65 \text { patients (2009-2012) }\end{array}$ & $\begin{array}{l}\text { To compare the } \\
\text { psychological attitude } \\
\text { of patients and } \\
\text { to determine the } \\
\text { most appropriate } \\
\text { psychological care } \\
\text { for patients with } \\
\text { temporary and } \\
\text { permanent stomas. }\end{array}$ & $\begin{array}{l}\text { Contrary to the initial } \\
\text { presumption, body image } \\
\text { scale, self-esteem scale and } \\
\text { BDI did not show a significant } \\
\text { difference between PS and TS } \\
\text { group. }\end{array}$ \\
\hline $\begin{array}{c}\text { Salome GM, de } \\
\text { Almeida SA, } \\
\text { Silveira MM. } \\
\text { (20) }\end{array}$ & $\begin{array}{l}\text { Clinical, primary, } \\
\text { descriptive, } \\
\text { analytical study } \\
70 \text { patients } \\
\text { with intestinal } \\
\text { stoma }\end{array}$ & $\begin{array}{c}\text { Three instrument- } \\
\text { questionnaire consisting } \\
\text { of questions on } \\
\text { demographics and stoma, } \\
\text { Rosenberg Self-Esteem } \\
\text { Scale/UNIFESP-EPM, and } \\
\text { Flanagan Quality of Life } \\
\text { Scale was used in the data } \\
\text { collection. }\end{array}$ & $\begin{array}{l}\text { To evaluate the clinical } \\
\text { and sociodemographic } \\
\text { factors and correlate } \\
\text { them to the self-image } \\
\text { and self-esteem of the } \\
\text { patients. }\end{array}$ & $\begin{array}{l}\text { The patients examined } \\
\text { exhibit low self-image and } \\
\text { self-esteem in connection } \\
\text { with activities that } \\
\text { characterize life with a stoma } \\
\text { and in sociodemographic } \\
\text { data, meaning that these } \\
\text { individuals had negative } \\
\text { feelings about their own } \\
\text { bodies. }\end{array}$ \\
\hline $\begin{array}{c}\text { Salome GM, et } \\
\text { al. (6) }\end{array}$ & $\begin{array}{c}\text { Clinical, primary, } \\
\text { descriptive, } \\
\text { analytical, } \\
\text { prospective } \\
\text { study }\end{array}$ & $\begin{array}{l}\text { The data has been } \\
\text { collected using } \\
\text { three instruments } \\
\text { (demographics } \\
\text { questionnaire, Flanagan } \\
\text { QOLS, and Subjective well- } \\
\text { being scale) in the period } \\
\text { from December } 2012 \text { to } \\
\text { May } 2013 \text {. } \\
70 \text { stoma patients }\end{array}$ & $\begin{array}{l}\text { Investigate the } \\
\text { subjective well-being } \\
\text { and quality of life. }\end{array}$ & $\begin{array}{l}\text { The study shows that the loss } \\
\text { of social status in patients } \\
\text { with a stoma, the social } \\
\text { stigma they face, suffering } \\
\text { from the embarrassment, low } \\
\text { self-image and self-esteem } \\
\text { results in low quality of life, } \\
\text { social isolation, and anxiety. } \\
\text { A great problem regarding the } \\
\text { patients' level of education } \\
\text { was identified, as it was } \\
\text { noted that most patients ( } 47 \\
\text { or } 67.14 \% \text { ) were illiterate. }\end{array}$ \\
\hline
\end{tabular}




\begin{tabular}{|c|c|c|c|c|}
\hline Author & Study type & Methods & Study aim & Conclusion \\
\hline $\begin{array}{c}\text { Andersson G, } \\
\text { Engstrom A, } \\
\text { Sodeberg S. (21) }\end{array}$ & $\begin{array}{l}\text { Open-ended } \\
\text { interview } \\
\text { study }\end{array}$ & $\begin{array}{l}\text { Five women who had } \\
\text { rectal cancer and received } \\
\text { colostomy procedures, and } \\
\text { remained professionally } \\
\text { active. }\end{array}$ & $\begin{array}{l}\text { To describe women's } \\
\text { experience of living with } \\
\text { a colostomy after rectal } \\
\text { cancer surgery. }\end{array}$ & $\begin{array}{l}\text { Additional rehabilitation } \\
\text { is needed, as well } \\
\text { as nursing care that } \\
\text { focuses on adjustment to } \\
\text { temporary or permanent } \\
\text { changes in life. }\end{array}$ \\
\hline $\begin{array}{l}\text { Da Silva } A L \text {, et al. } \\
\qquad(22)\end{array}$ & $\begin{array}{l}\text { A prospective } \\
\text { quantitative } \\
\text { comparative } \\
\text { case-control } \\
\text { study } \\
36 \text { partners of } \\
\text { patients with } \\
\text { a permanent } \\
\text { colostomy and } \\
72 \text { healthy } \\
\text { individuals }\end{array}$ & $\begin{array}{l}\text { Two groups of subjects } \\
\text { - spouses of people with } \\
\text { permanent colostomies } \\
\text { compared with those } \\
\text { of partners of healthy } \\
\text { individuals. }\end{array}$ & $\begin{array}{l}\text { To determine the way } \\
\text { in which partners of } \\
\text { patients with permanent } \\
\text { colostomies perceive } \\
\text { everyday life, especially } \\
\text { the sexual aspect of life. }\end{array}$ & $\begin{array}{l}\text { Reduction in sexual } \\
\text { interest and frequency } \\
\text { of intercourse compared } \\
\text { with the control group. } \\
\text { Health workers should } \\
\text { devote more time and } \\
\text { attention to educate } \\
\text { partners of people with a } \\
\text { stoma. }\end{array}$ \\
\hline $\begin{array}{l}\text { Zhang T, et al. } \\
\text { (23) }\end{array}$ & $\begin{array}{l}\text { Descriptive } \\
\text { correlation } \\
\text { study }\end{array}$ & $\begin{array}{c}\text { Four scales were used - } \\
\text { EORTC QLQ -C30, EORTC } \\
\text { QLQ-CR38, ADS, SRQS. } \\
\text { From Aug. } 2011 \text { to Feb. } \\
2012 \\
111 \text { colostomy patients }\end{array}$ & $\begin{array}{l}\text { To explore the QOL and } \\
\text { acceptance of disability } \\
\text { and social support of } \\
\text { colostomy patients as } \\
\text { well as the relationship } \\
\text { between these factors. }\end{array}$ & $\begin{array}{l}\text { The sexual functioning } \\
\text { had the lowest function } \\
\text { score and female sexual } \\
\text { problems had the highest } \\
\text { SY score. Patients feel } \\
\text { marginalized by society. } \\
\text { Relationship of the } \\
\text { highest quality is the } \\
\text { family relationship. } \\
\text { Emotional support and } \\
\text { care from family are } \\
\text { extremely important to } \\
\text { the patients. However, } \\
\text { they eschew social } \\
\text { activity and contacts in } \\
\text { the community. }\end{array}$ \\
\hline Leyk M, et al. (24) & $\begin{array}{c}\text { Multicentre } \\
\text { Qualitative } \\
\text { comparative } \\
\text { study }\end{array}$ & $\begin{array}{l}\text { Interview during monthly } \\
\text { meetings of colostomy } \\
\text { support groups. Three } \\
\text { groups of subjects: } \\
\text { 1st group - subjects living } \\
\text { with a colostomy for } 1 \\
\text { year or less } \\
\text { 2nd group - subjects living } \\
\text { with a colostomy for 1-5 } \\
\quad \text { years } \\
\text { 3rd group - subjects living } \\
\text { with a colostomy for more }\end{array}$ & $\begin{array}{l}\text { To evaluate the influence } \\
\text { of social and family } \\
\text { support on health-related } \\
\text { quality of life, while taking } \\
\text { into consideration time } \\
\text { elapsed after the ostomy } \\
\text { procedure. }\end{array}$ & $\begin{array}{l}\text { People with a higher } \\
\text { level of social support } \\
\text { from their families have } \\
\text { higher HRQOL. A positive } \\
\text { effect has been found } \\
\text { to be related to the time } \\
\text { elapsed from the surgery: } \\
\text { the longer the period of } \\
\text { living with an ostomy, the } \\
\text { greater the influence of } \\
\text { social support. }\end{array}$ \\
\hline
\end{tabular}




\section{Education and stoma marking}

With education, the focus is on self-care of the stoma and marking of the stoma site on the patients' abdomen (16). Numerous complications which often have a negative effect on the quality of life of ostomates and their families can be avoided by adequate marking and positioning of the stoma. Most frequent complications are content leakage, dermatitis, parastomal hernia, prolapse of the stoma, and stoma retraction. Nurses can have a key role in caring for patients with a stoma, both pre- and postoperatively (16). Nursing care of the stoma should begin at diagnosis, on the occasion of surgery indication and on the day of creating the stoma (20). The family should be included in the education process, in accordance with the patient's wishes. Enterostomal therapists are specialized nurses who have a special licence to take care of stomas, chronic wounds, and incontinence. Those patients who have not met with an enterostomal therapist and gotten their education before the operation and know the system can provide for them feel agitated and worried. What worries them most is whether the stoma will be placed in the best place possible (21). Sun at al. (18), conducted a qualitative analysis involving eight focus groups, trying to find out which are the specific troubles of the patients with permanent and long-terms ostomies, and the necessary adaptations to alleviate them. The largest bulk of the problems result from inadequately positioned stomas, due to the lack of preoperational marking. These problems are clothing adaptation, equipment problems (which result in leakage and skin damage), activity limitations, dietary adjustment, absence from work and early retirement. The designs and equipment of public toilets are a problem and concern in everyday life. Further research is needed to explore factors related to family knowledge and acceptance of ostomies, as well as the ways in which supportive environment can influence facing with and adjustment to the life of a person with a stoma. Danielsen and Rosenberg (16), explored in their case-control study how structured education influences the health-related quality of life of stoma patients. The conclusion was that specifically targeted educational programmes led by specially trained professional health workers improve HRQOL. Coca C et al. (4), corroborated in their multi-centre quasi-experimental prospective longitudinal study the justifiability of the existence of nurse specialists in ostomy care and their positive effect on
HRQOL. Salome at al. explored the subjective wellbeing and quality of life of patients from Brazil using Flanagan QOL Scale and Subjective well-being scale (SWBS). This study has shown the importance of the professional (nurse, doctor or psychologist) using comprehensible and simple language that is suited to the patient. Ostomy patients should be well guided, trained, and taught the skills necessary to take care of themselves, regardless of their level of education, age, or social status. The benefits of marking the place of the stoma on the abdomen as a technique of preoperational preparation along with adequate education have been explored by McKenna et al. (13). By comparing two focus groups, they confirmed that the group that underwent adequate education and marking of the stoma before the procedure reported significantly higher HRQOL than those who did not. Speaking about education, it is important to note the study of Hong KS at al. (10), which confirmed that preoperational education is left out from most of the urgent cases of implementing a temporary stoma, and the information given to the patient during hospital treatment is merely cursory. In spite of the expectation that the patients who will be living with a stoma for a short period (6 months - 1 year) will not have as low self-esteem and body image - they do. Therefore, even if they will be living with a stoma for a short period, patients with a stoma need to be educated accurately about living with a stoma.

\section{Self-esteem and quality of life}

The assessment of self-esteem is becoming increasingly important and necessary for the majority of ostomates. These people start experiencing life differently, which entails significant changes to their standard of living and rhythm of life. Thus, they may feel rejected, seeking seclusion because of their body odour and elimination of faeces through the abdomen (20). According to numerous research studies, their system of values becomes different with time. Along with malignant diseases, the majority of ostomates must face the radical change of their physical appearance and functioning. According to Trninic et al. (7), ostomates suffering from cancer express aspects of a more negative body image, lower social functioning, and higher levels of depression than patients without stomas. On the other hand, the study of Hong KS et al. (10), which compares permanent and temporary ostomates, tells us that, in spite of the aforementioned expectation that temporary 
ostomates should not suffer as badly from low selfimage, there is no significant difference between the two groups regarding their self-esteem. It has also been noted that both groups were suffering from depression. It was also found that the lower economic status of the patients, the higher the body image score. It is also important to note the fact that the change of self-esteem was in a way contingent upon the life, character traits, and expectations of the ostomates before the procedure has been undertaken. According to Salome at al. (2015) ostomized patients who had previously had low self-esteem and self-image also had negative feelings about their own bodies after the procedure, and those patients who previously had not had issues regarding their self-image and self-esteem, developed them after the procedure in relation to their stomas. According to Jang et al. (25), the quality of life of a permanent ostomate is at its lowest in the first month after the operation. After the third month following the operation, all the dimensions of functioning improve. Lian's study (26), tells us that global QOL, psychological functioning, carrying out social roles, cognitive, emotional and social functioning improved significantly in the third postoperative month. If no metastases developed in the six months following the operation and implementation of the gastrointestinal stoma, the patients generally accept their stomas and adapt to life with a stoma. Salome and Almeida (20) conducted research on the correlation between sociodemographic and clinical factors and self-image and self-esteem. After comparing data related to the stoma and sociodemographic profiles with the Rosenberg Self-Esteem Scale/UNIFESP and Body Investment Scale, it became obvious that all patients demonstrated a decrease in self-esteem and self-image. It is also important to note the fact that people who have not been notified that they would be subjected to ostomy and in whom no marking was done showed worsening in self-esteem and self-image in relation to other features related to injury and sociodemographic data.

\section{Family and quality of life}

Regarding family life and support, according to Andersson at al. (21), people with stomas do not consider themselves sexually attractive and are often apprehensive about their partners' reaction. Rectum operation may bring about anatomical changes in the vagina, causing pain during intercourse. Women experience problems of sexual nature more often. Most of these problems include apprehension regarding odour control, pouch management, or sexual positions that prevent pressure on the stoma. Da Silva et al. (22), confirmed in their research that sexuality plays a major role in maintaining a satisfying level of quality of life of stoma patients, their families and partners. Family support is essential, and spouses and partners directly experience the patient's changed life (27). Therefore, spouses and partners need to be included in the educational programmes in order to deal with the situation in the best possible manner. According to the statements of the interviewees, family and friends were important to them. While spending time with them, ostomates do not think about their stomas, or possible flatulence or sounds they make. Ability to work is also very important. Returning to their previous working environments is very important. Uneasiness occurs most often because of the bathroom issue and where they would change their bags (22). Leyk et al. (24), conducted research with three focus groups with the aim of getting an insight into the influence of social support of the family in relation to the time of living with a gastrointestinal stoma. The groups were divided and interviewed regarding the time they were living with stomas. Level of social support and HRQOL were not significantly related in persons living with a colostomy for less than a year. It is evident that time is an important factor for HRQOL since the whole family finds itself in an unknown situation when their member gets a stoma. The longer a person lives with a stoma, the stronger is the social support of the family. The family also has to go through a period of adaptation. Many interviewees also state that the more time passes, the more they regard ostomy procedure lifesaving or relieving treatment, which makes them face the situation more easily (22).

\section{Discussion}

The aim of this review was to examine patient-related studies describing ostomy education and marking and their influence on self-esteem and quality of the patient's and family life. Most often used methods of the above-described studies are descriptive, qualitative, and cross-sectional studies. All studies confirm 
that stoma has a negative influence on the patients' quality of life. When a patient receives a stoma, he/ she begins to face many changes in his/her daily life that occur not only on the physiological level, but also on psychological, emotional, and social levels. This has its consequences: suffering, pain, deterioration, uncertainty about the future and fear of rejection (6). When speaking about the quality of life of stoma patients, it is important to note that common questionnaires on the quality of life are not sensitive enough to detect specific effects of the stoma itself on the quality of life of the patient. With a multidimensional QOL instrument, focusing on the effects of the intestinal stoma, specific areas of concern of ostomates can be identified. They include physical well-being and symptoms, psychological well-being, social well-being and spiritual well-being (28). The analysis of the aforementioned research studies shows that the most commonly used validated questionnaires for assessing the quality of life of ostomates are: Short form 36 (SF-36), City of Hope, Health-related quality of life (HRQOL), Rosenberg Self-Esteem Scale/UNIFESP-EPM, Body image scale, Self-esteem scale, Beck depression inventory, The Flanagan quality of life scale, Subjective well-being scale (SWBS), Social relation Quality scale (SRQS), Ostomy adjustment scale, Cancer-specific Quality of life questionnaire (QOL - CR 38), the European Organization for Research and Treatment of Cancer Quality of life (EORTC QOL-C30), EQ-5D. Open-ended questions are also commonly used. In order to adequately compare results and studies, it is necessary to include as many countries as possible in the validation of the questionnaires and to conduct research studies regarding the assessment of the quality of life of patients with a stoma.

\section{Education and stoma marking}

Regarding the results on education and stoma marking research, it is important to note with the aim of improving the quality of life of stoma patients that it is vital to implement preoperational marking and to make sure that the patients get continuous education from specifically trained healthcare professionals. Regarding adaptation, another important aspect of it is the role of the healthcare professional in assisting the person with an ostomy from the period before surgery to hospital discharge, but it is also their role to help family and social environment to adapt. Enterostomal therapist, along with surgeons mark the place for the stoma. It is necessary to provide stoma marking and education, regardless of the urgency of the case. A duly done stoma that is adequately placed prevents numerous complications and is bound to improve the quality of life of the stoma patient.

\section{Self esteem}

Ostomates bring up negative aspects of the changes to their self-esteem. It is essential to sensitize the environment of the patient and strengthen the patient's self-esteem using the techniques of positive psychology.

\section{Family life}

The presence of the family in the adaptive period is fundamental to the patient; family members help with explanations, dialogue, advice, and, most importantly, convey comfort and safety and provide ways to accept being a person with a stoma (28). It is thus necessary to ensure support for the family members and include them in the process of education. Further research is needed regarding the review of family relations even after the patient's discharge from the hospital, so they could be opportunely provided with adequate support.

It is also important to conduct further research with the aim of improving sexual functioning and relations, which are often stated as problems by the partners of the patients.

\section{Limitations and strengths of this review}

The most important limitation of this review is the inclusion only of studies available in full which have been analysed. An important strength of this review is the collection and analysis of the most used methodology, sample sizes, aims and conclusions, as well as a list of studies available in the searched scientificmedical corpora in the last five years. The searched corpora contain only one study on this topic published in this region, which opens a wide space for further research. A lack of public health programmes for the people with stomas of the gastrointestinal tract has been noted. 


\section{Future research}

It is necessary to conduct validation of the questionnaires regarding the quality of life of stoma patients in Slovenia, Croatia, and other countries of the region in the future, so the results could be compared, the necessary corrective measures could be undertaken, and public health programmes for improving the quality of life of stoma patients could be developed. It is also necessary to strengthen educational programmes for ostomates and their families from the point of diagnosis, as long as they live with it, regardless of whether it is a permanent or temporary colostomy. It is also of vital importance to mark and adequately position stoma to all the patients who are suspected or known to need the ostomy procedure. Primary health care needs to strengthen educational programmes and programmes for monitoring the quality of life of ostomates and their families, such as patient flow and home care services. There is also space for research regarding sexual life of ostomates. Further research is needed in the field of quality of life of ostomates' families, and how they face the situation they find themselves in. It is also necessary to conduct research on the social environment and their awareness of ostomates.

\section{Conclusion}

Teaching the patient how to live with an ostomy can be a challenging experience for all healthcare professionals. The patient with an ostomy needs encouragement, support, and counselling to learn how to integrate self-ostomy care into daily activities. Evidence from studies show that adaptation to ostomy management and self-care is a long-term process, and readjustment is often needed when the individual's condition changes. Education and marking of the most acceptable place for the stoma have a major influence on the ostomates' self-esteem and quality of life of both ostomates' and their families. The patients and their families must be included in the processes of deciding, educational programmes, social support and continuous evaluation of the processes, from the point of diagnosis and throughout life. It is necessary to apply ostomy patient flow, strengthen the home care system, and public health systems of support for ostomates. Taking into consideration the insight in scientific corpora gained in this overview, there is a lack of research studies from Croatia, Slovenia, and the other countries of the region. More society education programs are needed to help patients and their family in order for their quality of life to be as high as possible.

\section{References}

1. Toth PE. Ostomy care and rehabilitation in colorectal cancer. Semin Oncol Nurs. 2006;22(3):174-7.

2. Kidd L, Kearney N, O'Carroll R, Hubbard G. Experiences of self-care in patients with colorectal cancer: A longitudinal study. J Adv Nurs. 2008;64(5):469-77.

3. Simmons KL, Smith JA, Bobb KA, Liles LL. Adjustment to colostomy: Stoma acceptance, stoma care selfefficacy and interpersonal relationships. J Adv Nurs. 2007:60(6):627-35.

4. Coca C, Fernández de Larrinoa I, Serrano R, García-Llana $\mathrm{H}$. The impact of specialty practice nursing care on health-related quality of life in persons with ostomies. J Wound Ostomy Continence Nurs. 2015;42(3):257-263.

5. Melotti LF, Bueno IM, Silveira GV, Silva Maria EN, Fedosse $E$. Characterization of patients with ostomy treated at a public municipal and regional reference center. J Coloproctol (Rio J). 2013; 33(2):70-4.

6. Salome GM, Almeida SA, Silveira MM. Quality of life and self-esteem of patients with intestinal stoma. J Coloproctol (Rio J.). 2014; 34(4):231-9.

7. Trninić Z, Vidačak A, Vrhovac J, Petrov B, Šetka V. Quality of Life after Colorectal Cancer Surgery in Patients from University Clinical Hospital Mostar, Bosnia and Herzegovina. Coll Antropol. 2009;33 supplement 2(2):1-5.

8. Ross L, Abild-Nielsen AG, Thomsen BL, Karlsen RV, Boesen $\mathrm{BH}$, Johansen C. Quality of life of Danish colorectal cancer patients with and without a stoma. Support Care Cancer. 2007;15(5):505-13.

9. Gervaz P, Bucher P, Konrad B, Morel P, Beyeler S, Lataillade $L$, et al. A Prospective longitudinal evaluation of quality of life after abdominoperineal resection. Jur Surg Oncol. 2008;97(1):14-29.

10. Hong KS, Oh BY, Kim EJ, Chung SS, Kim KH, Lee RA. Psychological attitude to self-appraisal of stoma patients: prospective observation of stoma duration effect to self-appraisal. Ann Surg Treat Res. 2014;86(3):152-60.

11. Brown $\mathrm{H}$, Randle J. Living with a stoma: a review of the literature. J Clin Nurs. 2005;14(1):74-81. 
12. Salvadalena G, Hendren S, McKenna L, Muldoon R, Netsch D, Paquette I, et al. WOCN Society and ASCRS Position Statement on Preoperative Stoma Site Marking for Patients Undergoing Colostomy or IIeostomy Surgery. J Wound Ostomy Continence Nurs. 2015;42(3):249-52.

13. McKenna LS, Taggart E, Stoelting J, Kirkbride G, Forbes $\mathrm{GB}$. The impact of preoperative stoma marking on health - related quality of life: a comparison cohort study. J Wound Ostomy Continence Nurs. 2016;43(1):80-7.

14. Reading LA. Stoma siting: what the community nurse needs to know. J Community Nurs. 2003;8(11):502-11.

15. Sands LR, Morales CS. Re-operative surgery for intestinal stoma complications. Semin Colon Rectal Surg. 2015; 26(4):200-5.

16. Danielsen AK, Rosenberg J. Patient education after stoma creation may reduce health-care costs. Dan Med J. 2014;61(4):A4659.

17. Cetolin SF, Beltrame V, Cetolin SK, Presta AA. Social and family dynamic with patients with definitive intestinal ostomy. Arq Bras Cir Dig. 2013;26(3):170-2.

18. Sun V, Grant M, McMullen CK, Altschuler A, Mohler MJ, Hornbrook MC, et al. Surviving colorectal cancer: long-term, persistent ostomy-specific concerns and adaptations. J Wound Ostomy Continence Nurs. 2013;40(1):61-72.

19. Golicki D, Styczen P, Szczepkowski M. Quality of life in stoma patients in Poland: multicentre cross-sectional study using WHOQOL-BREF questionnaire. Przegl Epidemiol. 2013;67(3):491-6, 589-93.

20. Salome GM, de Almeida SA, Silveira M.M. Association of sociodemographic and clinical factors with the selfimage and self-esteem of individuals with intestinal stoma. J Coloproctol (Rio J). 2014;34(3):159-66.
21. Andersson G, Engström $\AA$, Söderberg S. A chance to live: women's experiences of living with a colostomy after rectal cancer surgery. Int J Nurs Pract. 2010;16(6):603-8.

22. Da Silva AL, Monteiro PS, Sousa JB, Vianna AL, Oliveira PG. Partners of patients having a permanent colostomy should also receive attention from the healthcare team. Colorectal Dis. 2014;16(12):431-4.

23. Zhang TL, Hu AL, Xu HL, Zheng MC, Liang MJ. Patients after colostomy: relationship between quality of life and acceptance of disability and social support. Chin Med J (Engl). 2013;126(21):4124-31.

24. Leyk M, Ksiaz' ek J, Habel A, Dobosz M, Kruk A, Terech S. The influence of social support from the family on health related-quality of life in persons with a colostomy. J Wound Ostomy Continence Nurs. 2014;41(6):581-8.

25. Yang X, Li Q, Zhao H, Li J, Duan J, Wang D, et al. Quality of life in rectal cancer patients with permanent colostomy in Xi'an. Afr Health Sci. 2014;14(1):28-36.

26. Lian L, Wu XR, He XS, Zou YF, Wu XJ, Lan P, et al. Extraperitoneal vs. intraperitoneal route for permanent colostomy: a meta-analysis of 1,071 patients. Int J Colorectal Dis. 2012;27(1):59-64.

27. Souza JL, Gomes GC, Barros EJL. The care of person with ostomy: the role of family caregiver. Rev Enferm. 2009;17(4):550-5.

28. Vonk-Klaassen SM, de Vocht HM, den Ouden ME, Eddes $E H$, Schuurmans MJ. Ostomy-related problems and their impact on quality of life of colorectal cancer ostomates: a systematic review. Qual Life Res. 2016;25(1):125-33. 


\section{UČINCI PRIJEOPERACIJSKE EDUKACIJE, OZNAČAVANJA I PRIMJERENOG POLOŽAJA STOME NA SAMOPOUZDANJE I KVALITETU ŽIVOTA PACIJENATA SA STOMOM I NJIHOVIH OBITELJI}

\section{Sažetak}

Cilj. Svrha je ovog sustavnog pregleda proučiti sva dostupna istraživanja kvalitete života pacijenata sa stomom i njihovih obitelji, što ovisi o učincima primjerene prijeoperacijske edukacije, najboljeg i najprihvatljivijeg mjesta za stomu označenog na pacijentovu abdomenu te poslijeoperacijskom učinku na samopouzdanje pacijenta sa stomom.

Metode. Provedeno je istraživanje literature $s$ pomoću znanstvenih elektroničkih baza podataka Science Direct PubMed i Medline. Proučen je period između 2010. i 2016. kako bi se dobio uvid u najnovije rezultate istraživanja. Pri pretraživanju upotrijebljeni su sljedeći pojmovi: prijeoperacijska edukacija, označavanje mjesta za stomu, kvaliteta života, samopouzdanje, utjecaj na obiteljski život. Pregled članaka proveden je u tri faze.

Rezultati. Pronađeno je 1440 znanstvenih članaka. U prvoj fazi eliminiran je 1271 članak koji nije odgovarao istraživanju. $U$ drugoj fazi analizirana su 34 članka te je donesen zaključak na temelju 13 dostupnih cjelovitih tekstova.

Zaključak. Pacijent je zadovoljan za vrijeme liječenja u bolnici; no problemi nastupaju nakon otpuštanja iz bolnice, a često su uzroci nezadovoljstva, osamljenosti, anksioznosti i straha - sve to dovodi do snižene kvalitete života. Prijeoperacijska edukacija i označavanje najprihvatljivijeg mjesta za stomu znatno utječu na samopouzdanje i kvalitetu života pacijenata s ostomijom i njihovih obitelji. Potrebno je kontinuirano pratiti pacijente sa stomom te unaprijediti sustav kućne njege i sustav javnozdravstvene podrške za pacijente s gastrointestinalnom stomom.
Ključne riječi: prijeoperacijska edukacija, označavanje i primjeren položaj stome, kvaliteta života 